\title{
“The Black", Space, and Sexuality: Examining Resistance in Selvon's The Lonely Londoners
}

\author{
Patrick Herald \\ Forthcoming in The Journal of Commonwealth Literature: \\ http:/jcl.sagepub.com/content/early/2015/10/13/0021989415608906.abstract
}

doi:10.1177/0021989415608906

The opening sentence of Sam Selvon's The Lonely Londoners greets the reader with an allusion to T.S. Eliot's The Waste Land while describing a character's journey to meet a newly arrived immigrant from their native Trinidad. "One grim winter evening, when it had a kind of unrealness about London, with a fog sleeping restlessly over the city”, it reads, recalling Eliot's “Unreal city, / Under the brown fog of a winter dawn” (Selvon, 2010: 23, Eliot, 1971: 60-1). The reference Selvon makes here is so clear that it warrants consideration. Some parallels for those familiar with both texts will come to mind: both are fragmentary, leaping from character to character in Selvon's novel and speaker to speaker in Eliot's poem; both experiment with language, Eliot's by utilizing multiple languages and Selvon’s by employing a Trinidadian dialect $^{1}$; both explore the feeling of alienation in the twentieth century metropole. However, The Lonely Londoners deals explicitly with additional complications, namely colonial immigration and race. That is, Selvon's evocation of The Waste Land brings to mind the alienation of Eliot's monolithic poem not only at an individual level, but with an additional twist: the question of race as group identity. In other words, Selvon's Trinidadian characters carry an additional burden of

\footnotetext{
${ }^{1}$ Selvon employed a kind of hybrid dialect, though he did not see this as in any way inauthentic: rather, Selvon felt that he "had to consider being read by an audience outside the Caribbean to whom a presentation of the pure dialect would have been obscure and difficult to understand” (qtd in Ramchand, 1988: 99).
} 
imperial and racial oppression. Scholars have engaged usefully with group identity in the novel, with Kenneth Ramchand arguing that a growing group consciousness is "the process which the whole book may be said to be about”:

it is only through the development of consciousness that the group, tribe, clan, community or whatever can preserve its essential qualities while living as twentieth-century people. A defensive regression into the unthinking group is no better than the withdrawal into the tomb of Ralph Singh. ${ }^{2}$ For Moses, and presumably for Selvon, the birth of consciousness is the beginning of our participation in the perennial effort to sing simultaneously our songs of innocence and experience. (Song of Innocence, 1988: 232-3)

The process Ramchand identifies highlights a tension between group and individual consciousness; in the context of Selvon's postwar London, group identity comes with certain risks — such as a failure to develop a group consciousness beyond individual self-identificationeven in addition to the usual hazards minority groups might be exposed to. Too strong a focus on isolated individualism, then, might impede group expression.

It is no surprise that The Lonely Londoners brings up questions of race and empire. Selvon himself moved from Port of Spain to London in the 1950s (the novel was first published in 1956), and so experienced firsthand the disorientation of emigrating from one of the colonies to the center of imperial power. London is also an apt example of how the city, race, and colonialism intertwined in midcentury London — a phenomenon with implications not only for the decade of imperial decline during which The Lonely Londoners appeared, but the

\footnotetext{
${ }^{2}$ Of V.S. Naipul's The Mimic Men (1967).
} 
contemporary world. As David Theo Goldberg puts it, "It seems uncontroversial to claim that the roots of the racialized postmodern city can be traced to the end of the colonial era. Not until this juncture did the metropolises of the West have to confront directly the 'problem of the racially marginalized', of (re)producing racial marginalization in its own spaces” (1993: 187). Indeed, while Goldberg's focus here is broadly on cities in "the West" and not London in its particularity, the reproduction of racial marginalization he describes is on full display in The Lonely Londoners. It is not simply that the Trinidadian characters are directly antagonized and mistreated by whites - the city itself seems designed to marginalize them. "Keep the Water White", one sign reads ("the Water" referring to Bayswater in West London), and the arrangement of the city and its housing not only divides Trinidadians from whites but also from each other (Selvon, 2010: 89).

In considering those one sees as being victims of oppression, the question of how to resist forces which perpetuate such inequality quickly arises. This is a familiar question in colonial and postcolonial theory and criticism, from Frantz Fanon's work to the present. John McLeod, for example, argues in Postcolonial London (2004) "for a notion of the postcolonial which is connected to successful modes of resistance and transformation” (13). Sue Kossew provocatively calls for a return to literature in debates over resistance, arguing that "many of these debates about resistance and complicity ... can be refocused when the spotlight is not on the theory or the inflexible dogmatic application of theories, but on the literary texts themselves, which ... often enact and thematise the very slippery processes which the theory is trying to pin down" (1999: 19, emphasis in original). Kossew's point is well taken in that theoretical arguments can become, at times, exclusively self-reflective, with little or no direct reference or example- 
theory for theory's sake, in other words. While there is certainly something to be said for purely theoretical arguments, Kossew suggests that literary texts can be utilized to move outside of realm of the exclusively theoretical, providing a better look at the object of theory than either theoretical or exclusively literary analyses might offer. This is not altogether unfamiliar; literary critics certainly take up this task in the common move of using literature to illustrate a theoretical framework. What I take from Kossew's argument, though, is that literary works can function as a kind of primary text for theorists to grapple with, texts that are not only illustrative of theory that is deployed like a lens, but which operate in a more dialectical manner.

In the case of The Lonely Londoners, certain theoretical notions of resistance and agency prove inadequate for considering the complexities of the treatment of Selvon's Trinidadian characters. For example, to proceed from a binary logic of resistance and oppression carries the danger of universalizing those seen as oppressed, and smoothing over important complications in the novel; this is especially problematic in the literary realm, because such texts typically focus, explicitly at least, more on individual characters than groups. Kossew implies that while theory is useful in the literary arena, literary texts are also useful in the theoretical arena. And of course, a novel like The Lonely Londoners, written at a pivotal moment of imperial decline, offers a valuable perspective both on the experience of colonial immigration to England (and the accompanying complications of race and sexuality it wrought) as well as theories of resistance, both of which interest me. By drawing on work done on race and resistance by theorists such as Saba Mahmood, Slavoj Žižek, and Sara Ahmed_as well as scholars of postcolonial and Commonwealth literature-I hope to go beyond the sort of analysis which I admittedly fell into when I first encountered Selvon's novel, one which might impose a simplistic paradigm of 
resistance and oppression over the complex intersections of race and sexuality on display in the novel. I take inspiration in particular from Mahmood's excellent interrogation of resistance. What I am attempting, then, is to look more closely at resistance itself, neither to take it for granted, nor to assume it as desirable, even in the context of a culture which is accurately portrayed as oppressing groups like Selvon's fellow West Indian immigrants. More specifically, The Lonely Londoners can be seen as grappling with and critiquing resistance in light of individualism, one of liberalism's chief values. In Dwelling Places (2003), James Procter usefully identifies "a certain trivialization of, and lack of commitment to, the mobilisation of a black 'political' community by the boys of The Lonely Londoners" (60). Procter's observation highlights a central conflict; formally, the novel's title invokes a group ${ }^{3}$-yet the narrative itself spends a great deal of time detailing the individual lives of its characters, individual lives which stand in tension with their shared group identity and their daily struggles in postwar London. This tension between individualism and community reveals key moments—such as Galahad's personification of the color black - as being symptomatic of a complex field of identity categories that Selvon's novel engages with. I argue that these categories should indeed be interrogated alongside the novel's depictions of metropolitan geography; however, I suggest that such an analysis is best served by also treating a key concept that might be taken for granted with the same complexity and diligence: resistance.

\footnotetext{
${ }^{3}$ The Londoners identified by the novel's title presumably refer to the Trinidadian immigrants that are its central focus, though the possibility of the title referencing the London populace at large has implications for the group/individual tension, as it would imply loneliness as a common point of reference between what seem at times in the novel to be two different, white and black Londons. Paradoxically, though, loneliness may simultaneously be common ground and a stumbling block for community organization or mutual understanding, as the fragmentary nature of Selvon's London resists anything other than division, particularly by race and gender.
} 


\section{The hazards of resistance}

Before returning to The Lonely Londoners, I want to explore the notion of resistance more thoroughly. Perhaps for the very reason that resistance is such an obvious response to oppression, it has been called into question by numerous theorists. One of the most well-known critiques of resistance has been performed by Saba Mahmood, whose influential and controversial Politics of Piety responds to the push for Islamic women to resist oppression perpetrated by fundamentalist societies. In particular, Mahmood is troubled by the idea that resistance and agency are necessarily correlated terms. Her goal in Politics of Piety, she writes, is "to make this material speak back to the normative liberal assumptions about human nature ... such as the belief that all human beings have an innate desire for freedom, that we all somehow seek to assert our autonomy when allowed to do so, that human agency primarily consists of acts that challenge social norms and not those that uphold them” (2005: 5). By recasting resistance as a "liberal assumption", Mahmood effectively reveals it as a potentially misguided and universalizing trope rather than an axiom. She also questions the idea that agency is conceptually reliant on resistance. Mahmood goes on to interrogate resistance and agency through the binary of inner ideas and outer action. She argues that 'liberalism's unique contribution is to link the notion of self-realization with individual autonomy, wherein the process of realizing oneself is equated with the ability to realize the desires of one's 'true will'” (Mahmood, 2005: 11). In other words, liberalism, by its linking of self-conception with one's individualism implies that "realizing one's true will" is reliant on undermining norms. A non-liberal conception of agency might then incorporate the upholding of norms by way of more communal, less individualistic actions, not only actions that challenge norms. 
Mahmood's questioning of "liberal” views of agency and resistance are incredibly valuable as a counterpoint to the ubiquity of resistance narratives. Politics of Piety, I think, gestures toward the paradox that resistance itself can become normative. If agency relies on individuals resisting oppression, then it rests on an uncomplicated resistance/oppression binary which mandates resistance for resistance's sake. This becomes especially troublesome when outside observers interject with the assumption that anyone whom they see as being oppressed must therefore be unhappy and impelled to resist. It is from this perspective that Mahmood asks "whether it is even possible to identify a universal category of acts-such as those of resistance-outside of the ethical and political conditions within which such acts acquire their meaning” (2005: 9). She goes on to detail the "equally important" question of whether the very category of resistance imposes "a teleology that makes it hard for us to see and understand forms of being and action that are not necessarily encapsulated by the narrative of subversion and reinscription of norms” (Mahmood, 2005: 9). Mahmood, then, calls into question not only the utility of resistance, but also implies that it could be an actively harmful concept, one that sets up a sort of blind spot biased toward the notion of individual will contained in the liberal framework, one that might smooth over complications and contradictions.

Mahmood's insightful investigation of the category of resistance is particularly useful in exposing a vulnerability in a concept often taken for granted. Goldberg makes a lucid point when he argues that "conceptual contention is necessary at the very least to conceiving the ordered imposition of the terms of social subjectivity as symbolic violence, necessary to seeing the established conditions of subjectivity as domination” (1993: 9, emphasis in original). This statement is, at face value, fairly straightforward: resistance to an existing order necessitates not 
Herald 8

accepting the conceptions of the dominant order at face value, but instead challenging them and perhaps proposing alternatives. For example, a resistance reading of The Lonely Londoners could examine the most identifiable example of a character who actively communicates a theoretical, or perhaps philosophical, idea: Galahad, the Trinidadian whom Moses (arguably the novel's protagonist) meets at the beginning of novel. Galahad formulates an idea after he has been in London for some time and has an awkward encounter in the street. By this time, he has begun to make a concerted effort to differentiate his appearance out on the town from his appearance at work, so much so that "if you bounce up Galahad one morning by the tube station when he coming from work, you won't believe is the same fellar you did see coasting in the park the evening before” (Selvon, 2010: 86). Galahad's tailored outfits seem to help him fit in—or feel as though he does — so that he walks "cool as a lord", greeting every passerby "and not giving a blast if they answer or not" (2010: 87). It is in this context that Galahad is identified by race by a young child who exclaims “"Mummy, look at that black man!’” (2010: 87). While the mother chides the child, Galahad "bend down and pat the child cheek, and the child cower and shrink and begin to cry” (2010: 87). Galahad still tries to take on the affectation of an Englishman, mimicking the accent and asking the child's name, but the mother was "uneasy" and "pull the child along and she look at Galahad and give a sickly sort of smile, and the old Galahad, knowing how it is, smile back and walk on” (2010: 88). It is after this scene that Galahad begins to formulate his theory.

After the uncomfortable encounter with the white woman and her child, Galahad finds himself angry with the color black itself. Indeed, he begins reifying it in a way, communicating with it directly. "Colour, is you that causing all this, you know", Galahad says, and goes on, 
"telling it that is not he [Galahad] who causing botheration in the place, but Black, who is a worthless thing for making trouble all about” (Selvon, 2010: 88, emphasis in original). He wonders "why the hell” Black “can’t change color” (Selvon, 2010: 89). It is this externalization of blackness that Galahad sees as a revolutionary idea, and he is excited enough by it idea that he is compelled to tell Moses: "Is not we that the people don't like . . . is the colour Black" (Selvon, 2010: 89). In at least one sense, Galahad is correct: whites in the novel who act in racist ways never do so out of a genuine knowledge of individual Trinidadian characters and a subsequent reasoned judgment call, but always by invoking group markers. This is also a moment when Galahad engages with group identity, invoking a "we" that both he and Moses belong to; yet at least one common aspect of this group, blackness, is identified as a stumbling block for individual fulfillment. The division he imagines between "the Black" and what we assume he imagines to be his "true" self also recalls the spatially divisive London of the novel. Ultimately, it is difficult to see Galahad's theory as being politically productive in the sense of "conceptual contention” Goldberg outlines above. As McLeod notes, "sadly, even if oppressed peoples intend and attempt resistance at a local level, it does not always follow that their tactics have significant global impact” (2004: 13). Indeed, in the case of Galahad's theorizing, there is no significant local impact either.

Galahad reasons through his theory by conceiving of "the Black" as something incidental to his real identity, an unpleasant hanger-on he wishes people could see past; the implication Galahad seems to be aiming for is that, yes, he is black, but beyond that he is a likable person who does not intend people harm. At first glance, this may seem commonsensical. Slavoj Žižek introduces a crucial complication to this line of reasoning, however. He makes the argument that 
“an interpellation succeeds precisely when I perceive myself as 'not only that', but a 'complex person who, among other things, is also that' - in short, imaginary distance towards symbolic identification is the very sign of its success” (Žižek, 2008: 306). While Galahad accurately recognizes the arbitrary nature of "the Black" as an aspect of identity, he still views it as "a worthless thing" that is "making trouble”. A resistance reading of The Lonely Londoners, then, would contend that Galahad's theory is not radical enough: it attempts a separation between blackness and "true" identity, and does little to challenge the racial category itself, or do the work of "conceptual contention". That is, Galahad simply externalizes blackness, dissociating it from his real or inherent identity. It is also clear that the separation Galahad envisions will go unrecognized by the dominant culture; indeed, Žižek’s view of interpellation suggests that Galahad's theory demonstrates a successful interpellation rather than worthwhile resistance against it. In other words, Galahad may placate only himself, potentially accepting his underprivileged position in society by imagining — correctly, but not usefully—-that whites are simply failing to see his complex personhood and instead only considering the collective mark of blackness, a naïve theory that makes no move to undermine their broader view of race.

The above analysis may be a perfectly acceptable reading of Galahad; however, I cannot help but see it as resting on the same predictable resistance/oppression binary Mahmood's work encourages us to look beyond. The resistance reading follows through on the assumption that the novel's Trinidadian characters are being oppressed by a colonial, white, normative ideology, and so need to find entry points for resistance. Even if true, though, by taking this as the starting point for analysis, the argument makes a universalizing gesture not altogether unlike the universalizing colonial gesture. Such a reading simplifies the complex situation these immigrant 
characters occupy, effacing differences which might offer a more complicated look at the metropolis during the final years of the empire-a complex situation Selvon carefully crafted as well. Such a reading thus does not do justice to the experience The Lonely Londoners depicts, nor to the novel itself. Mahmood does not argue that resistance is altogether a useless category, however. Certainly Politics of Piety as a whole takes greater issue with the way resistance is deployed by writers (particularly Mahmood's liberal targets) than it does with the concept itself. The question Mahmood's questions lead to, then, is how to think about resistance more productively, or to take a step further, how to imagine a new concept altogether.

\section{"Scattering the boys around": race, space, and agency}

It is difficult, in thinking about race in a colonial context, not to consider the work of Frantz Fanon. In Black Skin, White Masks, Fanon makes some of the stronger statements about race and gender in the critical canon. Late in the book, Fanon asserts that "the black man is comparaison. That is the first truth. He is comparaison in the sense that he is constantly preoccupied with self-assertion and the ego ideal. Whenever he is in the presence of someone else, there is always the question of worth and merit” (2008: 185-6, emphasis in original). Fanon's point goes deeper than suggesting that all black men are alike in that they are all preoccupied with themselves as compared to others. Earlier, he describes how "the white world. . . demanded of me that I behave like a black man—or at least like a Negro. I hailed the world, and the world amputated my enthusiasm. I was expected to stay in line and make myself scarce” (Fanon, 2008: 94). The ambivalence Fanon describes, then, is couched in personal experience. His attempt at self-assertion ("I hailed the world") is quickly rebuffed by the social order he occupies. Fanon remarks that "the black man should no longer have to be faced with the 
dilemma 'whiten or perish,' but must become aware of the possibility of existence” (2008: 80). Before assuming that this is another simple binary (the black man should resist by asserting himself, and should never become like the whites who oppress him), it is worth paying close attention to how Fanon follows this statement. Describing his own goals as a psychoanalyst, Fanon states that his "objective will be to enable [his patient] to choose action (or passivity) with respect to the real source of the conflict, i.e., the social structure” (2008: 80, my emphasis). Here Fanon makes an argument reminiscent of the one Mahmood makes over 50 years later: agency should not necessarily involve undermining a social structure. Passivity is a real option for Fanon; what is crucial is the ability to choose. The social structure referred to here is inextricably bound up with the concept of race, and so Fanon's focus is on those who are marginalized by race. Rather than insist that individuals must act against the system of oppression they are under, Fanon complicates things by pointing instead toward the idea of choice rather than resistance as the only possibility.

Consider Moses, perhaps the most complex character in The Lonely Londoners; his treatment of newer Trinidadian arrivals carries important implications for any reading of resistance and agency in the novel. Peter Kalliney describes how "as a coping strategy, many of the characters, including Moses, adopt a jaded, haughty attitude toward the city and their fellow urbanites” (2006: 107). Indeed, one of the defining aspects of Moses as a character is his apparent reluctance to help his peers_-yet he generally does, eventually. As a relative London veteran, he inadvertently finds himself in the position of helping new arrivals get on their feet, and "it look to Moses that he hardly have time to settle in the old Brit'n before all sorts of fellars start coming straight to his room in the Water when they land up in London from the West 
Indies” (Selvon, 2010: 23-4). Despite his reluctance-“I don’t know why the hell you come to me" he says - Moses relates to the newcomers, and "he went out with them, because he used to remember how desperate he was when he was in London for the first time and didn't know anybody or anything” (Selvon, 2010: 25). Despite his gruff demeanor, Moses attracts the new arrivals like a beacon, and it quickly becomes apparent that this is for good reason: not only is he willing to help, but he is also savvy and intelligent. Moses also seems to recognize the importance of space, as "like a welfare officer Moses scattering the boys around London, for he don't want no concentrated area in the Water-as it is, things bad enough already” (Selvon, 2010: 25). Goldberg optimistically writes that "to change one’s geography—not only to move from but equally to transform one's spaces and its representations-may well be to change one’s world” (1993: 205). However unrealistic this may seem in the context of 1950s London, Moses does demonstrate awareness that concentrating the racially marked Trinidadian immigrants in one location will damage employment possibilities and lower the quality of life of the broader Trinidadian community. By "scattering the boys around", Moses makes an early attempt to undermine the constriction of his countrymen into a single ghetto-like area of London.

As much assistance as he offers his fellow immigrants, one move Moses does not make is attempt to communicate a theorization of the position Trinidadians find themselves in in the novel. Neither, for that matter, does the narrator of the novel, who toward the end becomes increasingly easy to conflate with Moses himself. This is important because it leaves open the possibility for another reading of Moses "scattering the boys around": namely, that by so distributing them, Moses may be shielding them from some effects of ghettoization, yet simultaneously undermining their ability to mobilize as a group. In other words, if agency is 
understood as the challenging of norms, Moses’ distribution of the boys can be read as sabotaging their agency: by increasing the difficulty of mobilizing as a group, he is denying them an important avenue for effecting change in social norms, since their isolation and fragmentation only diminishes their power further. However, Moses deliberately scatters them; if this move guards them to some extent from ghettoization, it can be read as opening up one opportunity (for Trinidadians to exist in more areas of London, with perhaps greater access to work, welfare services, and so on) at the expense of another (to mobilize as a group and attempt to bring about social change). If the idea of Trinidadian immigrants mobilizing in 1950s London to bring about substantial changes in their standard of living and reducing inequality seems like a long shot, this is no doubt well-understood by Moses. In effect, he is using a defensive strategy: realizing that governmental apparatuses (and the white populace at large) are unlikely to hear the immigrants out, Moses simply scatters them so they are more difficult to target. It is significant that this is a deliberate decision by Moses, yet it seems unfair to accuse him of denying the Trinidadians agency by impairing their ability to challenge social norms directly. J. Dillon Brown points out that even in rare moments the boys have a chance to speak publicly about their living conditions - as when Big City manages to get Galahad a window of opportunity at the Orator's Corner-they simply do not take it seriously:

By depicting such a scene-the most pronounced chance offered the characters for some kind of public discourse about the racism on which the novel concentrates - Selvon suggests that it is not only the ignorance and misplaced fear of the white British population that are at fault. The refusal of the boys to engage 
seriously with socially sanctioned mechanisms for contact with the native population also contributes to the disunity so prominent in the city. (2013: 127) Considering the lack of serious engagement on the part of his fellow immigrants in these scenes, the veteran Londoner Moses may well scatter them in part out of a lack of faith in their current potential for engaging with white Britons as a group.

Treating agency as resistance to social norms in this context presents an odd paradox: Moses would be exercising agency (challenging the norm of ghettoized housing) by denying his fellow immigrants agency (stymying their ability to protest as a group). It seems more useful to focus on choice as a form of agency here rather than norm-challenging: Moses recognizes two options and chooses the strategy that appears most advantageous to his fellows. Mahmood argues that "we should keep the meaning of agency open", and that it, as a concept, "should be delinked from the goals of progressive politics” (2005: 34). Indeed, Moses scattering the boys around is a way of enacting the meaning of agency as something that "cannot be fixed in advance, but must emerge through an analysis of the particular concepts that enable specific modes of being, responsibility, and effectivity” (Mahmood, 2005: 14-15). Just as Mahmood argues in The Politics of Piety that the piety movement in Egypt cannot be effectively understood by placing it within the boundaries of a resistance/oppression binary which fails to grapple with Islamic women involved with the movement as enacting a form of agency, so I argue that the reading of Galahad's blackness theory in the above section—as a failed attempt at necessary resistanceencourages us to likewise gloss over the intricacies of the scattering performed by Moses. Fanon's argument also implicates "the social structure" in the issue of race, a move taken up by many theorists working with race in recent years, and a move which draws attention to 
race not as a biological category, but a constructed and imposed one. The result is that race can go unnoticed for those groups the social structure favors while permeating everything for others. Charles W. Mills conjures an evocative image when he writes that "the fish does not see the water, and whites do not see the racial nature of a white polity because it is natural to them, the element in which they move” (1999: 76). Sara Ahmed argues along similar lines that "race becomes given insofar as it does not have our attention" (2006:131). However, "whiteness is only invisible to those who inhabit it, or for those who get so used to its inhabitance that they learn not to see it, even when they are not it” (Ahmed, 2006: 133, my emphasis). This is an important perception, for it speaks to the anxiety Fanon ascribes specifically to blacks. If we consider whiteness as a category so normative that it becomes a given, even invisible, it is possible to see how a specifically racial anxiety can arise. That is, if someone not considered white becomes "so used to [whiteness's] inhabitance" that they no longer notice it, as Ahmed suggests is possible, then whiteness become non-raced. In other words, members of other races can become (and be made to become) conscious of their racial status, and then that awareness can manifest itself in a variety of ways.

In considering white normativity in this way, it is worth returning to Galahad's color theory. Galahad, the newly-arrived Trinidadian the reader meets in the opening pages of the novel, quickly finds himself forced to think about race in ways he presumably had not done up until this point. After the white woman recoils from him when he greets her child, Galahad formulates a theory of his own. He "watch the colour of his hand, and talk to it, saying, 'Colour, is you that causing all this, you know. Why the hell you can't be blue, or red or green, if you can't be white? You know is you that cause a lot of misery in this world'” (Selvon, 2010: 88). 
When Galahad begins "talking to the colour Black, as if it is a person . . . a worthless thing for making trouble all about”, identifying with the negative racial categorization of blackness, he is viewing himself as marked by this excess of blackness, something desirably absent from whites (Selvon, 2010: 88). And indeed, this is the same phenomenon Fanon notes when he writes that "the identification process means that a black child subjectively adopts a white man's attitude" (2008: 126). And unquestionably, while Galahad is not a child, he is cast in The Lonely Londoners as an innocent new arrival, previously separated from the particular racial politics of the white metropolis. When Galahad accepts blackness as a negative mark, he thus takes on the viewpoint of white racists who view it from that very perspective. McLeod argues that Galahad's mobility as he walks through London "represents a modest victory ... over London's powers of arrest", he correctly highlights how "the child's remark turns Galahad into the object of a racializing gaze which threatens to curtail his agency” (2004: 36-7). It is this Althusserian hailing that puts Galahad on uneven footing when he undertakes racial analysis. When Galahad explains his theory, Moses wryly tells him: “'Take it easy, that is a sharp theory, why don’t you write about it,"” perhaps in an effort to convince Galahad to slow down and think through the politically ineffective theory more carefully (Selvon, 2010: 89). Writing as a reflective activity here may also be revealing in the context of Selvon's expressed views on identity: "For Selvon, the nature of his position as a Trinidadian rather than an Indian enabled what he has termed a 'wider outlook on life and the world.' Yet, he has also said that at some point the whole issue of identity must be faced on a private level” (Nasta, 1988: 4). In this sense, Galahad may need to, in Selvon's eyes, work out his theory individually before approaching members of a wider group to present it. 


\section{Sexuality and racialised bodies}

There is also a clear intersection between race as group identity and sexuality in the novel, one implied by Galahad's interaction with the mother above, but dealt with more directly elsewhere. As detailed above, the city of London operates almost as a character in its own right in The Lonely Londoners. The way Selvon depicts London carries implications for how those seen as belonging to different races as well as different genders interact in the novel. Asef Bayat points out that "the modern city has a tendency to differentiate, individualize, and fragment its inhabitants, to weaken the traditional ties, break down extended family ... and increase geographic mobility" (2009: 188). To a degree, Bayat's argument is in line with how critics have viewed London in the novel. The issue of fragmentation is something Kalliney notes in analyzing The Lonely Londoners, arguing that "the fragmented, lonely Londoners yearn for deeper connections, a possibility explored through the text's restless, constantly shifting narrative” (2006: 106). ${ }^{4}$ This tendency also plays out with a racial twist; as Procter observes, 'housing is an exclusionary environment in The Lonely Londoners, imposing an architecture of segregation and individuation” (2003: 45). Yet Bayat's reference to geographic mobility is also important to consider in the context of Selvon's novel, perhaps most usefully in relation to the Ulysses-echoing section describing summer in the city. ${ }^{5}$

\footnotetext{
${ }^{4}$ Indeed, this fragmentation is also implied in the allusions to fragmented modernist texts such as The Waste Land, as described above.

${ }^{5}$ A stream-of-consciousness narrative made up of one seemingly endless sentence, the section echoes the final chapter of Ulysses which details Molly Bloom reflecting on whether or not to take her husband back after having an affair. The parallels between the two texts are reinforced by the subject matter of the section, which features reference to cuckolding, among other sexual encounters.
} 
What makes the description of summer in The Lonely Londoners appropriate to consider alongside Bayat's description of the modern city is its focus on place and mobility. The central feature of the section is Hyde Park, where various liaisons take place, including those between white Londoners and Caribbean immigrants. The park becomes a kind of contact zone where member of different classes and races congregate to satisfy their carnal desires. Rather than recoil from black characters here, proximity seems to be acceptable and even desired by white characters. This key section has been much written about. In a recent article, Kate Houlden complicates earlier analyses that take issue with its apparent lionization of stereotypical tropes of black sexuality. While I have noted the tension between group and individual identity, Houlden picks up on a "double-edged" engagement between white and black characters in the summertime section: “All, it seems, are equally lost within the racialised sexual economies of post-war London”, she writes (2012: 24, 28). Houlden’s article reveals a significant ambivalence in the summer encounters; I hope to add a reading of space to that analysis, one that clarifies the role of resistance in the novel. Ahmed's analysis of space and proximity in racialised bodies is useful here:

Not only is the whiteness of the white body endangered by some of the proximities it inherits, but some forms of proximity with bodies that are marked by difference are permitted: proximity to such others can even 'confirm' the whiteness of the body. 'Others' might then become resources for extending the reach of the white body. (Ahmed, 2006: 128)

This permission of proximity to difference is on display in one moment when Moses is picked up by a woman and taken to a white club. While there, "Moses sit down there wondering how this 
Herald 20

sort of thing happening in a place where only the high and the mighty is but with all of that they feel they can't get big thrills unless they have a black man in the company” (Selvon, 2010: 109). I read this as a moment in which the idea of whiteness is being confirmed by its contrast with and simultaneous proximity to the black body. The final step is "when Moses leave afterwards they push five pounds in his hand and pat him on the back and say that was a jolly good show" (Selvon, 2010: 109). This patronizing gesture functions as a method of "extending the reach of the white body”, as Ahmed puts it; it retains the difference between races and also confirms the difference in power between Moses and the white club-goers: not only is he paid off afterward, the gesture signals that when he leaves, it is on their terms, just as he arrived on their terms when he was driven there.

A more directly sexual encounter involves Moses and a white couple who pick him up in the park and invite him to their home. Moses "went just to see what would happen and what happen was the fellar play as if he fall asleep and give Moses a free hand because it have fellars who get big thrills that way" (Selvon, 2010: 105). In this scene, it is important to note that while Moses seems to be viewed through a racial lens to touch on the fantasy of this man, Moses does not reciprocate: instead, Moses only notes that "some" fellars get thrills this way. Indeed, he seems to have encountered it before, and he “didn’t do anything because he know what the position like and even though the fellar offer him three pounds he smile and was polite and tell him that he sorry good night” (Selvon, 2010: 105). It is here, I think, that we see a kind of agency on Moses's part. Mahmood makes the point that 'if we think of 'agency' not simply as a synonym for resistance to social norms but as a modality of action, then this conversation raises some interesting questions about the kind of relationship established between the subject and the 
norm, between performative behavior and inward disposition” (Mahmood, 2005: 157). Rather than viewing Moses's refusal as a universalized form of resistance-Moses refuses oppressive white power the opportunity to gain enjoyment by turning its gaze on his body in the sexual act-his act reveals his agency within a situation that is in fact not the norm. Clearly picking up any man and asking him to sleep with one’s partner is, at the very least, formally taboo. Moses enacts his agency in this individual situation by both inwardly reflecting on it ("he know what the position like”) and acting outwardly (“sorry good night”). Moses’s refusal to act on this fantasy also reveals how the park operates as a place of mobility, not only geographically but socially. As an informally agreed-upon meeting place for blacks and whites alike, the park allows situations to be created that leave room for agency on the part of black characters. In other words, Moses has some, albeit limited, agency here.

Even as these racialised sexual encounters open up potential space for agency, they nonetheless sometimes enact violence through the racialised fantasies taken on by white characters. The narrator explains how as a black person “you can’t put on any English accent for them ... or try to be polite and civilize they don't want that sort of thing at all they want you to live up to the films and stories they hear about ... the cruder you are the more they like you the whole blasted set of them” (2010: 108). The fantasy of the black man as crude, uncivilized, and sexual is pervasive in this section of the novel, which also notes how the "crudest" men get "real sharp chicks” (2010: 108). This plays out when an unnamed Jamaican man goes home with a white woman from an art exhibit, and "in the heat of emotion she call the Jamaican a black bastard though she didn't mean it as an insult but as a compliment under the circumstances” (Selvon, 2010: 109). The Lacanian definition of fantasy offers one way of looking at this 
sequence: "fantasy functions as a construction, as an imaginary scenario filling out the void, the opening of the desire of the Other: by giving us a definite answer to the question 'What does the Other want?'” (Žižek, 1999: 114-5, emphasis original). Here, the white woman’s fantasy is dependent on the racialised fantasy of blackness as signifying an uncivilized, savage sexuality. The trouble, of course, is that this is a social invention, and so her outburst quickly runs up against the reality of the Jamaican man's angry reaction: he 'thump the woman and went away' (Selvon, 2010: 109).

There are two forms of violence at work in the encounter between the white woman and the Jamaican man. One is physical and obvious - he hits her before departing in anger. The more complicated violence, though, is the violence of a universalizing fantasy thrust upon the Jamaican man. His disgust is not only a direct result of the insult, but a reaction to the realization that he is operating as a mere placeholder in this woman's fantasy, an object. The "black bastard" comment is thus insulting on two levels: the immediacy of the bastard epithet as well as the inclusion of blackness, a comment that effaces the man's individuality by covering it over with the group marker of black skin color. The implied supplementing of hypersexual and violent tendencies onto the man's black body has the end result of obscuring white violence (by imagining black violence in its place) and covering over black individuality. Indeed, as Kalliney notes of the novel's Trinidadian characters, "although their racial difference is something of which they and their fellow Londoners are acutely aware, it is a difference that effaces their individuality in the eyes of most white subjects” (2006: 108). The group identity of the Trinidadian characters paradoxically offers an inroad to just that-a form of identity-while also subjectivizing them as other than the norm. These sexual encounters which deploy a fantasy of 
bestial blackness are thus effectively a disciplinary measure whose aim is to universalize and control blackness by denying individuality.

\section{Conclusion}

In light of these specific meetings between black and white characters in The Lonely Londoners, I want to make a final consideration of Galahad's notion of "the Black" in the context of Sara Ahmed's Queer Phenomonelogy. Ahmed provocatively invokes blackness when she writes that she 'love[s] the use of the word 'black' as a reorientation device, as a political orientation, despite the ways in which it can risk concealing the differences between bodies” (2006: 156). Her reasoning is that "such a word becomes an object, which gathers us around as a regathering and helps ground the work that we do, in part by redescribing the ground as the ground of whiteness. Such a word, claimed in this way, points toward the future and toward a world that we have yet to inhabit: a world that is not orientated around whiteness" (Ahmed, 2006: 156). In Ahmed’s extended spatial metaphor of racial and sexual politics, then, "black” can become an orientating device that works in a counter fashion to white supremacy. By identifying "the ground" as that of whiteness, one might resultantly imagine an alternative space (we might recall Mills here as well). This is the step Galahad does not take- he invokes blackness and recognizes it as a category not inherent to his individual identity, but does nothing to interrogate whiteness in the same fashion. As a result, he is left with no solutions, and his theory drops away, not heard from again in the novel. Considering the various meetings that begin at the park, however, may point to something more productive. Ahmed makes the point that "in feeling angry about racism, and for how we have been diminished by it, we create new spaces - we expand the very space occupied by our bodies, as an expansion that involves 
political energy and collective work” (2006: 155). Here we might recall the Jamaican man who reacts with outrage at the epithet hurled at him during sex; we might also recall Moses's choice to depart when he realizes the situation he is in with the white couple and their cuckold fantasy. The choice to depart after being transported by whites to white spaces reflects the geographic mobility Bayat notes in the modern city, but also demonstrates how black characters in these contexts are able to take control of these situations that are rooted in the (relatively) equal grounds of the park: they decide who to go with, and they leave on their own terms. The downside, of course, is that the fragmentary nature of life in the city and the fact that the characters take these actions only individually and in isolation means that these events seem unlikely to encourage the kind of collective work Ahmed imagines.

It is clear that facile notions of resistance and agency alone are inadequate for considering the complexities of the treatment of Selvon's Trinidadian characters. Rather than proceeding from a binary logic of resistance and oppression, which carries the danger of universalizing those seen as oppressed, I have attempted to analyze these characters in the specific contexts of the novel, in an effort to allow Selvon's text to speak back to theory, rather than to deploy theory as a lens - a method of critique that can easily become an exercise for its own sake. It may be that this analysis appears unproductive when held up to a broader theory (of resistance or otherwise). However, I argue that Mahmood usefully demonstrates the shortcomings some of these theories may face. In the case of Selvon and other writers who deal with oppression, one might fail to analyze not only who might resist, but also the critic —or the self —who views their resistance as a necessity. Jasbir Puar notes that "to be excused from a critique of one's own power relations is the appeal of white liberalism” (2007: 31). This is the trap that imposing a model like 
resistance/oppression might fall into, and which I have attempted to avoid in this analysis in hopes of producing a critically reflexive analys is, one perhaps in the spirit of what McLeod identifies in The Lonely Londoners itself: "a hopeful dream of change directly responsive to, rather than ignorant of, social realities” (2004: 40, emphasis original). 
Works Cited

Ahmed, Sara (2006) Queer Phenomenology: Orientations, Objects, Others. Durham, NC: Duke UP.

Bayat, Asef (2009) Life as Politics: How Ordinary People Change the Middle East. Stanford: Stanford UP.

Brown, Dillon J. (2013) Migrant Modernism: Postwar London and the West Indian Novel. Charlottseville, VA: U of Virginia P.

Eliot, T.S. (1971) The Waste Land. In: Collected Poems 1909-1962. New York: Harcourt Brace Jovanovich, pp.51-76.

Fanon, Frantz (2008) Black Skin, White Masks. New York: Grove Press.

Goldberg, David Theo (1993) Racist Culture; Philosophy and the Politics of Meaning. Cambridge, MA: Blackwell.

Houlden, Kate (2012) Sam Selvon's The Lonely Londoners (1956), White Sexual Desire and the Calypso Aesthetic. Journal of West Indian Literature 20.2 (2012): 24-37.

Kalliney, Peter (2006) Cities of Affluence and Anger: A Literary Geography of Modern Englishness. Charlottesville, VA: U of Virginia P.

Kossew, Sue (1999) Resistance, complicity and post-colonial politics. Critical Survey 11.2 (1999): 18-30.

Mahmood, Saba (2005) Politics of Piety: The Islamic Revival and the Feminist Subject. Princeton, NJ: Princeton UP.

McLeod, John (2004) Postcolonial London: Rewriting the Metropolis. London: Routledge. Mills, Charles W (1999) The Racial Contract. Ithaca, New York: Cornell University Press. 
Nasta, Susheila, ed. (1988) Critical Perspectives on Sam Selvon. Washington, DC: Three Continents Press.

Procter, James (2003) Dwelling Places: Postwar Black British Writing. Manchester: Manchester University Press.

Puar, Jasbir (2007) Terrorist Assemblages: Homonationalism in Queer Times. Durham, NC: Duke UP.

Ramchand, Kenneth (1988) Sam Selvon talking: a conversation with Kenneth Ramchand. In: Susheila Nasta (ed) Critical Perspectives on Sam Selvon. Washington, DC: Three Continents Press, pp.95-104.

Ramchand, Kenneth (1988) Song of Innocence, Song of Experience: Samuel Selvon's The Lonely Londoners as a Literary Work. In: Susheila Nasta (ed) Critical Perspectives on Sam Selvon. Washington, DC: Three Continents Press, pp.223-233.

Selvon, Sam (2010) The Lonely Londoners. New York: Longman.

Žižek, Slavoj (1999) The Sublime Object of Ideology. New York: Verso.

Žižek, Slavoj (2008) The Ticklish Subject: The Absent Centre of Political Ontology. New York: Verso. 